\title{
PENGARUH PENAMBAHAN MENIR JAGUNG PADA PAKAN AYAM TERHADAP PERTAMBAHAN BOBOT AYAM BROILER DI DESA WOTAN KECAMATAN SUMBEREJO
}

\author{
INFLUENCE OF ADDITION OF CHICKEN FEED ON CORN GROATS \\ AGAINST CHICKEN BROILER WEIGHTS ADDED IN SUMBEREJO SUB- \\ DISTRICT WOTAN VILLAGE
}

Eka Juli Wijaya Putra1, Drh. Muridi Qomaruddin, MM2, Ir. Mufid Dahlan Mma3

${ }^{1}$ Mahasiswa Fakultas Peternakan

${ }^{2}$ Dosen Pembimbing Utama

${ }^{3}$ Dosen Pembimbing Pendamping

Program Studi Peternakan

Fakultas Peternakan, Universitas Islam Lamongan (UNISLA)

\section{RINGKASAN}

Dari hasil penelitian ini dapat disimpulkan bahwa beberapa tingkat penambahan menir jagung dalam pakan jadi finisher tidak memberikan pengaruh yang nyata ( $\mathrm{P}>0,05$ ) terhadap konsumsi pakan dan pertambahan bobot badan. Secara teknis penambahan menir jagung dalam pakan jadi finisher yang paling baik sebesar 10 persen, karena menunjukan pertambahan bobot badan yang tinggi disbanding dengan ransum yang lain, walaupun menunjukan pakan konsumsi yang tinggi. Secara ekonomis penambahan menir jagung dalam pakan jadi finisher yang paling baik sebesar 25 persen, karena menunjukan biaya yang termurah, walaupun menunjukan pakan yang tinggi juga menunjukan pertambahan bobot badan yang rendah. Untuk mendapatkan pertambahan bobot badan yang tinggi, disarankan menambahkan menir jagung sebesar 10 persen dalam pakan jadi agar kebutuhan akan protein dan energi tetap terpenuhi.

From these results it can be concluded that some degree of increase in feed corn groats so finisher no significant effect $(\mathrm{P}>0.05)$ on feed consumption and body weight gain. Technically the addition of maize groats in the feed so the best finisher by 10 percent, as it shows that high body weight gain compared with other rations, although the feed showed high consumption. Economically increase in finished feed corn groats best finisher by 25 percent, because it shows the lowest cost, despite high feed showed also showed lower body weight gain. To obtain a high body weight gain, suggested adding corn groats by 10 percent in the feed so that protein and energy needs remain unfulfilled.

\section{PENDAHULUAN}

Karakter keberhasilan usaha peternakan ayam ditentukan tiga faktor pentingya itu bibit, pakan dan manajemen. Menurut Suroprawiro, Siregar dan Sabrani (1981), faktor bibit menentukan keberhasilan sebesar 20 persen, makanan 30 persen dan manajemen 50 persen. Bila ditinjau dari biaya produksi, maka biaya pakan merupakan biaya terbesarnya itu berkisar antara 60-70 persen (Anonimous, 1982; Murtijo, 2005 ;dan Santoso, 1987).

Banyak peternak merasakan biaya pakan merupakan beban berat karena sering terjadi fluktuasi harga pakan yang cenderung naik. Kenaikan harga pakan disebabkan oleh kenaikan harga bahan pakan pokok seperti jagung, bungkil kedelai dan tepung ikan (Murtidjo, 2005).

Dilihat dari segi keuntungan, maka peternak ayam dalam posisi yang lemah. Melihat kondisi demikian banyak peternak mencari alternatif dengan cara mengganti atau menambahkan bahan yang lebih murah, mudah diperoleh dan bergizi tinggi tanpa mengurangi mutu produk dalam pakan jadi.

Pakan jadi yang dibuat oleh pabrik pakan ternak diproduksi tidak untuk satu daerah tertentu, tetapi dibuat secara umum untuk semua jenis daerah dengan memperhatikan standart kebutuhan zat-zat pakan tertentu jika diberikan pada ternak pada daerah yang tertentu. Sehingga salah satu alternatif yang diberikan oleh peternak untuk memenuhi 
kekurangan zat pakan tersebut adalah dengan menambahkan dalam pakan jadi tersebut dengan bahan pakan yang lain yang kaya zat yang dibutuhkan.

Menir jagung merupakan hasil sampingan dari proses penggilingan jagung, dapat digunakan sebagai bahan penyusun ransum unggas, karena mempunyai kandungan zat-zat pakan cukup tinggi serta tidak bersaing dengan konsumsi manusia. Realita menir jagung telah banyak digunakan oleh peternak sebagai bahan penyusun ransum ayam terutama untuk ayam pedaging (broiler).

Penggunaan jagung bagi pakan ternak terutama unggas rata-rata berkisar 45-55 persen porsinya. Hal ini karena jagung mempunyai banyak keunggulan dibandingkan bahan baku lainya. Dua diantara keunggulan jagung adalah kandungan energinya yang bisa mencapai $3.350 \mathrm{kcal} / \mathrm{kg}$ ( NRC 1994 ) dan xantophil yang cukup tinggi. Dari sisi asam amino jagung dipandang sebagai bahan yang cukup kaya akan methionine ( rasio ) sehingga kombinasi jagung dengan sumber lysin seperti soybean meal dirasa cukup baik dalam penyusunan ransum. Jagung kuning merupakan bahan baku ternak dan ikan yang populer digunakan di Indonesia dan di beberapa negara. Jagung digunakan sebagai bahan baku penghasil energi, tetapi bukan sebagai bahan sumber protein, karena kadar protein yang rendah ( 8,9 persen ), bahkan defisien terhadap asam amino penting, terutama lysindan tripofan.

UD. Sumber Makmur terletak di Desa Wotan Kecamatan Sumberejo Kabupaten Bojonegoro. Jumlah ayam yang dipelihara di UD. Sumber Makmur yang berlokasi di Desa Wotan Kecamatan Sumberejo berjumlah 32.000 ekor, menurut survey di Kecamatan Sumberejo UD. Sumber makmur merupakan peternakan terbesar di Kecamatan Sumberejo dan mempunyai data paling unggul di bandingkan dengan peternakan lain yang ada di wilayah Kecamatan Sumberejo dalam aspek hasil panen.
Tabel 1: Kandungan Nutrisi Jagung

\begin{tabular}{l|l}
\hline $\begin{array}{l}\text { Bahan } \\
\text { kering }\end{array}$ & $75-90$ persen \\
\hline $\begin{array}{l}\text { Serat } \\
\text { kasar }\end{array}$ & 2,0 persen \\
\hline $\begin{array}{l}\text { Protein } \\
\text { kasar }\end{array}$ & 8,9 persen \\
\hline $\begin{array}{l}\text { Lemak } \\
\text { kasar }\end{array}$ & 3,5 persen \\
\hline $\begin{array}{l}\text { Energi } \\
\text { gross }\end{array}$ & $3.370-3.918 \mathrm{kkal} / \mathrm{kg}$ \\
\hline Niacin & $26,3 \mathrm{mg} / \mathrm{kg}$ \\
\hline $\begin{array}{l}\text { TDN } \\
\text { Calcium }\end{array}$ & 82 persen \\
\hline \begin{tabular}{l} 
Fosfor \\
\hline $\begin{array}{l}\text { Asam } \\
\text { pantotenat }\end{array}$
\end{tabular} & $3,02 \mathrm{persen}$ \\
\hline $\begin{array}{l}\text { Riboflavin } \\
\text { Tiamin }\end{array}$ & $1,3 \mathrm{mg} / \mathrm{kg}$ \\
\hline Sumber $: \mathrm{USD}$ \\
\hline
\end{tabular}

\section{MATERI DAN METODE}

Materi yang digunakan adalah120 ekor ayam pedaging yang berumur 21 hari, produksi PT. CEOMAS. Dengan berat badan awal rata - rata 770 gram dan koenfisien keragaman 7 persen.

\section{METODE PENELITIAN}

Metode penelitian adalah percobaan menggunakan pola Rancangan Acak Lengkap (RAL) dengan enam perlakuan dimana masing-masing ulangan terdiri dari 5 ekor ayam.

Perlakuan yang diberikan adalah :

Perlakuan I : Pakan jadi finisher $100 \%$ tanpa penambahan menir jagung sebagai control $\left(\mathrm{R}_{\mathrm{O}}\right)$.

Perlakuan II : Pakan jadi finisher $100 \%$ ditambah 5\% menir jagung $\left(\mathrm{R}_{1}\right)$. 
Perlakuan III : Pakan jadi finisher 100\% ditambah $10 \%$ menir jagung $\left(\mathrm{R}_{2}\right)$.

Perlakuan IV : Pakan jadi finisher 100\% ditambah $15 \%$ menir jagung $\left(\mathrm{R}_{3}\right)$.

Perlakuan V : Pakan jadi finisher 100\% ditambah $20 \%$ menir jagung $\left(\mathrm{R}_{4}\right)$.

Perlakuan VI : Pakan jadi finisher 100\% ditambah $25 \%$ menir jagung $\left(\mathrm{R}_{5}\right)$.

Jumlah pemberian pakan menyesuaikan umur ayam mulai umur 21 hari sampai 35 hari sesuai dengan standart kebutuhan konsumsi pakan harian ayam.

Kemudian ditambah $10 \%$ dari kebutuhan konsumsi pakan harian untuk mengetahui atau agar dapat menghitung konsumsi pakan pada setiap perlakuan dan ulangan setiap harinya.

\section{ANALISIS DATA}

Data konsumsi pakan dan pertambahan bobot badan di analisa dengan menggunakan analisis ragam. Bila terdapat perbedaan yang nyata dilanjutkan dengan uji beda nyata terkecil untuk mencari perbedaan antar perlakuan ( Sastrosupadi, 1977 dan Yitnosumarto, 1989 ).

Model matematik dikemukakan sebagai berikut :

$\mathrm{Y}_{\mathrm{iJ}}=\pi+\tau_{1}+€_{\mathrm{iJ}}$

Dimana :

$\mathrm{Y}_{\mathrm{iJ}}=$ nilai pengamatan dalam perlakuan ke I ulangan ke j.

$\Pi=$ nilai tengah umum

$\tau_{1}=$ pengaruh perlakuan ke $\mathrm{i}$.

$\epsilon_{\mathrm{iJ}}=$ kesalahan percobaan pada perlakuan ke $\mathrm{i}$ ulangan ke $\mathrm{j}$.

$\mathrm{i}$ = banyaknya perlakuan

$\mathrm{j}=$ banyaknya ulangan pada perlakuan $\mathrm{i}$.

Melalui analisis ragam untuk mengetahui pengaruh perlakuan dengan uji F.

Hipotesis yang dikemukakan adalah :

$\mathrm{H} 0=\tau_{\mathrm{o}}=\tau_{\mathrm{j}}=\tau_{2}=\tau_{3}=\tau_{4}=\tau_{5}$
H I = Paling sedikit ada salah satu perlakuan berbeda dengan yang lain.

Apabila uji $\mathrm{F}$ teryata berpengaruh, maka untuk menentukan perlakuan yang mana berpengaruh dilakukan Uji Beda Nyata Terkecil VJ (BNT) dengan rumus sebagai berikut :

BNT $(\infty) \mathrm{t}_{\mathrm{ab}}^{\infty / 2}$ acak $=\frac{\sqrt{2 X K T \text { Acak }}}{n \text { ulangan }}$

\section{HASIL DAN PEMBAHASAN}

\section{Konsumsi Pakan}

Data konsumsi ayam per ualangan dari masing - masing perlakuan dapat dilihat pada Tabel 6 dibawah ini.

Tabel 9 : Data Konsumsi Pakan Ayam Percobaan Umur 5 Minggu :

\begin{tabular}{|c|c|c|c|c|c|c|}
\hline \multirow[t]{2}{*}{$\mathrm{P}$} & \multicolumn{4}{|c|}{ Ulangan } & \multirow{2}{*}{$\begin{array}{c}\text { Jumla } \\
\mathrm{h}\end{array}$} & \multirow{2}{*}{$\begin{array}{c}\text { Rata - } \\
\text { rata }\end{array}$} \\
\hline & 1 & 2 & 3 & 4 & & \\
\hline R0 & 2165 & 2176 & 2173 & 2169 & 8683 & 217075 \\
\hline R1 & 2189 & 2194 & 2198 & 2199 & 8780 & 2195 \\
\hline $\mathrm{R} 2$ & 2205 & 2208 & 2197 & 2211 & 8821 & 2205.25 \\
\hline R3 & 2173 & 2177 & 2181 & 2173 & 8704 & 2176 \\
\hline R4 & 2184 & 2188 & 2165 & 2162 & 8699 & 2174,75 \\
\hline R5 & 2171 & 2178 & 2179 & 2186 & 8714 & 2178,5 \\
\hline $\begin{array}{l}\text { Tota } \\
1\end{array}$ & & & & & 52401 & \\
\hline
\end{tabular}

Sumber : Data Primer Diolah ( 2016 )

Dari hasil penelitian menunjukan konsumsi pakan yang cukup tinggi pada ayam diberi ransum kontrol dan ransum yang ditambah menir jagung sebesar 5 persen. Pada kondisi ini energi yang terkandung dalam pakan lebih rendah, sehingga ayam mengkonsumsi pakan lebih banyak untuk memenuhi kebutuhan energinya. Hal ini sesuai dengan pendapat Siregar, dkk ( 1980 ) dan Murtidjo (2005 ), bahwa ayam pedaging 
cenderung meningkatkan jumlah konsumsi pakan bila kadungan dalam ransum rendah.

Ayam diberi pakan dengan ransum yang ditambah menir jagung sebesar 10 persen, menunjukkan konsumsi pakan yang tertinggi walaupun secara statistic tidak berbeda dengan ransum kontrol.

Tabel 10 : Sidik Ragam Dari Konsumsi Makanan:

\begin{tabular}{|c|c|c|c|c|c|c|}
\hline \multirow{2}{*}{$\begin{array}{c}\text { Sumb } \\
\text { er } \\
\text { Kerag } \\
\text { aman }\end{array}$} & \multirow{2}{*}{$\begin{array}{c}\text { Der } \\
\text { ajat } \\
\text { Beb } \\
\text { as }\end{array}$} & \multirow{2}{*}{$\begin{array}{c}\text { Jum } \\
\text { lah } \\
\text { Kua } \\
\text { drat }\end{array}$} & \multirow{2}{*}{$\begin{array}{l}\text { Kua } \\
\text { drat } \\
\text { Ten } \\
\text { gah }\end{array}$} & \multirow{2}{*}{$\begin{array}{c}\mathrm{F} \\
\text { hit }\end{array}$} & \multicolumn{2}{|c|}{ F table } \\
\hline & & & & & $\begin{array}{l}5 \\
\%\end{array}$ & $1 \%$ \\
\hline $\begin{array}{l}\text { Perlak } \\
\text { uan } \\
\text { Galat }\end{array}$ & $\begin{array}{c}5 \\
18\end{array}$ & $\begin{array}{c}370 \\
2,38 \\
915, \\
25 \\
\end{array}$ & $\begin{array}{c}123 \\
4,13 \\
50,8 \\
5 \\
\end{array}$ & $\begin{array}{l}24, \\
27\end{array}$ & $2,77^{\prime}$ & $\begin{array}{l}4, \\
25 \\
* *\end{array}$ \\
\hline Total & 23 & $\begin{array}{l}461 \\
7,63\end{array}$ & & & & \\
\hline
\end{tabular}

Sumber : Data Primer Diolah ( 2016 )

Keterangan: $\quad(*)$ Berbeda nyata.

$(* *)$ Berbeda sangat nyata

Berdasarkan Tabel $10 \mathrm{~F}$ hitung $>\mathrm{F}$ tabel pada taraf $5 \%$ dan $1 \%$, hal ini menunjukan bahwa ada perbedaan sangat nyata pada jumlah konsumsi pakan.

Ransum yang ditambah dengan menir jagung sebesar 5,15,20, dan 25 persen.pada kondisi ini ayam dalam kondisi pertumbuhan yang optimum, dan menghasilkan pertambahan bobot yang maksimum. Pakan yang dikonsumsi lebih banyak yang dirombak dalam bentuk jaringan tubuh dan lemak tubuh sehingga menghasilkan ayam - ayam yang gemuk.Disamping itu juga pakan lebih banyak dikonsumsi untuk memenuhi kebutuhan energy dalam mempertahankan kondisi tubuh dari temperature lingkungan. Hal ini sesuai dengan pendapat Wahyu

( 1978), bahwa konsumsi ransum tergantung pada besar ayam, suhu sekeliling, fase produksi dan kandungan energi ransum.

\subsection{Pertambahan Bobot Badan}

Data pertambahan bobot ayam per ualangan dari masing - masing perlakuan dapat dilihat pada tabel dibawah ini.

Tabel 11 : Data Pertambahan Bobot Ayam 5 minggu :

\begin{tabular}{|c|c|c|c|c|c|c|}
\hline \multirow[t]{2}{*}{ I } & \multicolumn{4}{|c|}{ Ulangan } & \multirow[t]{2}{*}{ Jumlah } & \multirow{2}{*}{$\begin{array}{l}\text { Rata- } \\
\text { rata }\end{array}$} \\
\hline & 1 & 2 & 3 & 4 & & \\
\hline $\mathrm{R}$ & 4841 & 4791 & 4773 & 4747 & 19152 & 4788 \\
\hline 0 & 4804 & 4768 & 4767 & 4895 & 19234 & 4808, \\
\hline $\mathrm{R}$ & 4787 & 4778 & 4819 & 4876 & 19260 & \\
\hline 1 & 4768 & 4769 & 4747 & 4795 & 19079 & 4815 \\
\hline $\mathrm{R}$ & 4876 & 4758 & 4839 & 4765 & 19238 & 4769, \\
\hline 2 & 4750 & 4754 & 4749 & 4795 & 19048 & 75 \\
\hline $\mathrm{R}$ & & & & & & $\begin{array}{l}4809, \\
5\end{array}$ \\
\hline $\mathrm{R}$ & & & & & & 4762 \\
\hline $\mathrm{D}$ & & & & & & \\
\hline K & & & & & & \\
\hline $\mathrm{T}$ & & & & & 11501 & \\
\hline ot & & & & & & \\
\hline al & & & & & & \\
\hline
\end{tabular}

Tabel 12 : Sidik Ragam Pertambahan Bobot Ayam

\begin{tabular}{|c|c|c|c|c|c|c|}
\hline \multirow{2}{*}{$\begin{array}{c}\text { Sumbe } \\
\text { r } \\
\text { Kerag } \\
\text { aman }\end{array}$} & \multirow{2}{*}{$\begin{array}{c}\text { Der } \\
\text { ajat } \\
\text { Beb } \\
\text { as }\end{array}$} & \multirow{2}{*}{$\begin{array}{c}\text { Juml } \\
\text { ah } \\
\text { Kuad } \\
\text { rat }\end{array}$} & \multirow{2}{*}{$\begin{array}{c}\text { Kuad } \\
\text { rat } \\
\text { Teng } \\
\text { ah }\end{array}$} & \multirow[t]{2}{*}{$\begin{array}{c}\text { F } \\
\text { hit }\end{array}$} & \multicolumn{2}{|c|}{$\mathrm{F}$ table } \\
\hline & & & & & $\begin{array}{l}5 \\
\%\end{array}$ & $\begin{array}{l}1 \\
\%\end{array}$ \\
\hline $\begin{array}{l}\text { Perlak } \\
\text { uan } \\
\text { Galat }\end{array}$ & $\begin{array}{c}5 \\
18\end{array}$ & $\begin{array}{c}1007 \\
3,88 \\
3402 \\
8,75\end{array}$ & $\begin{array}{c}3357, \\
96 \\
1889 \\
0,49\end{array}$ & $\begin{array}{l}0, \\
18\end{array}$ & $\begin{array}{c}2,7 \\
7\end{array}$ & $\begin{array}{l}4, \\
25\end{array}$ \\
\hline Total & 23 & $\begin{array}{c}4410 \\
2,63\end{array}$ & & & & \\
\hline
\end{tabular}

Sumber : Data Primer Diolah ( 2016 )

Berdasarkan Tabel $10 \mathrm{~F}$ hitung $<\mathrm{F}$ tabel pada taraf $5 \%$ dan $1 \%$, hal ini

menunjukan bahwa tidak ada perbedaan yang nyata pada pertambahan bobot badan ayam.

Dari hasil penelitian ini menunjukan $\mathrm{R}_{0}$ tidak berbeda dengan $R_{1}, R_{2}, R_{3}, R_{4}$, dan $R_{5}$. Dengan penambahan menir jagung dalam pakan jadi finisher dengan kandungan energy metabolis menir jagung sebesar $3200 \mathrm{kkal} / \mathrm{kg}$, maka penambahan energy dalam ransum akan berubah seperti Tabel dibawah ini.

Tabel 13 : Kandungan Energi Dengan Penambahan Menir Jagung. 


\begin{tabular}{l|c}
\hline $\begin{array}{c}\text { Penambahan } \\
\text { Menir Jagung }\end{array}$ & Energi \\
\hline 5 persen $\left(\mathrm{R}_{1}\right)$ & $3222,34 \mathrm{kkal} / \mathrm{kg}$ \\
\hline 10 persen $\left(\mathrm{R}_{2}\right)$ & $3244,68 \mathrm{kkal} / \mathrm{kg}$ \\
\hline 15 persen $\left(\mathrm{R}_{3}\right)$ & $3267,02 \mathrm{kkal} / \mathrm{kg}$ \\
\hline 20 persen $\left(\mathrm{R}_{4}\right)$ & $3289,36 \mathrm{kkal} / \mathrm{kg}$ \\
\hline 25 persen $\left(\mathrm{R}_{5}\right)$ & $3311,7 \mathrm{kkal} / \mathrm{kg}$ \\
\hline
\end{tabular}

Sumber : Murtidjo ( 2005 )

Seandainya kandungan energy dalam ransum pakan jadi finisher minimal 3000 $\mathrm{kkal} / \mathrm{kg}$ ( seperti dalam table 5 ), sedang kebutuhan energy untuk broiler menurut Anggorodi ( 1985 ) adalah 2800 - 3400 $\mathrm{kkal} / \mathrm{kg}$, maka dengan penambahan menir jagung sebesar $5,10,15,20$ dan 25 persen diperkirakan telah mencukupi kebutuhan energy.

Temperature kandang cukup tinggi dapat dilihat di daftar Lampiran 14. Akibat temperatur badan ayam akan mengeluarkan panas secara terus - menerus. Karena itu ayam memerlukan pakan yang banyak mengandung energy untuk menggantikan panas atau energy yang hilang ( Fadilah 2005 ). Dari pertambahan bobot badan seperti pada ( Lampiran 2 ), dengan penambahan menir jagung sebesar 10 persen menunjukkan pertambahan bobot badan yang tertinggi. Pada kondisi ini energy yang dibutuhkan oleh ayam tercukupi dan dalam kondisi optimum, sehingga akan menghasilkann pertambahan bobot yang maksimum.

Pada ransum kontrol tanpa penambahan menir jagung dan ransum dengan penambahan jagung sebesar 5 persen, diasumsikan kebutuhan energy untuk mempertahankan kondisi tubuhnya terhadap temperature lingkungan. Namun karena kapasitas tempolok terbatas, ayam tidak dapat mengkonsumsi pakan lebih banyak lagi untuk memperoleh energy.kurangnya energy tersebut akan mengganggu pertumbuhan dan menghasilkan pertambahan bobot badan yang rendah. Hal ini sesuai dengan pendapat Anggorodi ( 1985 ), yang menyatakan bahwa ransum yang berenergi rendah akan menghasilkan ayam ayam yang kurus karena ayam tidak dapat mengkonsumsi cukup energy untuk memperoleh pertumbuhan yang normal dan tidak akan menimbun lemak dalam jumlah yang cukup normal di dalam jaringan tubuhnya. Dan sesuai pendapat Rasyaf ( 2004
), yang menyatakan bahwa energy dibawah kebutuhan pokok maka ternak akan kehilangan berat karena ternak menggunakan protein tubuh untuk energi.

Ransum yang ditambah dengan menir jagung sebesar 15,20 , dan 25 persen menunjukan pertumbuhan bobot badan yang relative lebih rendah dibandingkan dengan ransum kotrol, ransum yang ditambahkan dengan menit jagung 5 dan 10 persen, walaupun secara statistic tidak berbeda nyata. Dalam kondisi ini energy yang terkandung dalam pakan telah mencukupi kebutuhan energi untuk hidup pokok. Kelebihan tersebut akan disimpan sebagai cadangan energi dalam bentuk lemak. Karena kandungan energy dalam pakan berkaitan dengan kandungan protein, sedangkan ayam mengkonsumsi pakan untuk memenuhi kebutuhan energinya, makan dengan penambahan menir jagung dalam pakan jadi sebesar 15,20 , dan 25 persen diperkirakan kebutuhan protein masih belum terpenuhi. Ayam tidak dapat memnuhi kebutuhan protein tersebut karena ayam tidak dapat mengkonsumsi ransum lebih banyak lagi, sehingga ayam akan mengalami kekurangan protein yang berakibat terhadap turunya pertumbuhan bobot badan. Hal ini sesuai dengan pendapat Anggorodi ( 1985 ), yang menyatakan tingkatan protein berkaitan dengan kadungan energy ransum, maka kekurangan protein yang ringan akan mengakibatan pertumbuhan menurun, kekurangan yang parah akan mengakibatkann penghentian pertumbuhan dengan segera dan kehilangan pertumbuhan yang menyolok, berkisar antara $5-7$ persen dari pertimbangan bobot badan per hari.

\section{KESIMPULAN DAN SARAN}

1. Kesimpulan

Dari hasil penelitian ini dapat disimpulkan bahwa beberapa tingkat penambahan menir jagung dalam pakan jadi finisher tidak memberikan pengaruh yang nyata $(\mathrm{P}>0,05)$ terhadap pertambahan bobot badan, sedangkan beberapa tingkat penambahan menir jagung dalam pakan jadi finisher menunjukan beda nyata dan sangat nyata $(\mathrm{P}>0,05)$ terhadap konsumsi pakan.

Secara ekonomis penambahan menir jagung dalam pakan jadi finisher yang paling baik sebesar 25 persen, karena menunjukan 
biaya yang termurah, walaupun menunjukan pakan yang tinggi juga menunjukan pertambahan bobot badan yang rendah.

2. Saran

Untuk mendapatkan pertambahan bobot badan yang tinggi, disarankan menambahkan menir jagung sebesar 10 persen dalam pakan jadi agar kebutuhan akan protein dan energi tetap terpenuhi.

\section{DAFTAR PUSTAKA}

Anggorodi, R. 1985. Kemajuan Mutakhir Dalam Ilmu Makanan Ternak Unggas. Universitas Indonesia Press. Jakarta.

Anonimus, 1982. Petunjuk Praktis Pemeliharaan Ayam Pedaging. Departemen Pertanian Direktorat Jenderal Peternakan, Satuan Tugas Pelaksanaan Kepres No. 50 / 1981. Jakarta.

Dedi Suryanto, 1992. Ilmu Pakan Ternak Unggas. Fakultas Peternakan. Universitas Islam Malang. Malang.

Fuad, T, 1987. Usaha Peternakan Ayam Potong. Akademi Pressindo.Jakarta.

Hadi Suparto, S. 1980. Teknik dan Manajemen Ayam Jantan Pedaging. C. B. Wonder Pharmacheutical Indonesia. Jakarta.

Indarto, P. 1986, Manajemen Ternak Unggas. Universitas Brawijaya. Malang.

Koenjoko, 1974. Petunjuk Praktis Beternak Ayam Daging. Departemen Ilmu Makanan Ternak. Fakultas Peternakan Unibraw. Malang.

Lubis, A. 1961.Ilmu Makanan Ternak. Yayasan Pembangunan.

Maharadun kamsi. 1987. Pemeliharaan Anak Ayam Periode Brooding, dalam Majalah Poultry Indonesia, Edisi VIII Th. 1992.

Muntolib, B, A. 2005. Pedoman Meramu Pakan Unggas. Kanisius. Yogyakarta.

Rasyaf, M. 2004. Beternak Ayam Pedaging. Penebar Swadaya. Jakarta.

Reksohadiprodjo, S. 1984. Pengantar Ilmu PeternakanTopik. BPFE.Yogyakarta.

Santoso, U. 1987. Limbah Bahan Ransum Unggas Yang Rasional. Bharaiara KaryaAksara. Jakarta.

Siregar, A P. ,Sabrani, M, dan Suroprawiro, P. 1980. Tehnik Beternak Ayam
Pedaging di Indonesia. Margie Group. Jakarta.

Suci, D, M. 1987. Jagung Sebagai Bahan

Pakan. Dalam Majalah Swadaya

Peternakan Indonesia. Edisi No.35/36

Desember 1987- Januari1988 : 31 .

Suparyanto, A.1987. Perhitungan

Kebutuhan Protein Bagi Ayam Ras,

dalam Majalah Poultry Indonesia.

Edisi VII Th. 1986.

Suroprawiro, P, Siregar, A, P, dan Subari, M. 1981. Tehnik Beternak Ayam Ras di Indonesia. Margie Group. Jakarta.

Tilman, A. D, Hartadi, H., Reksohadiprodjo, S., Prawirokusumo, S., dan Lebdosoekottjo, S. 1986. Ilmu Makanan Ternak Dasar. Gajah Mada Universitas Press. Yogyakarta.

Wahyu, S. dan Indarsih, B. 1987. Percobaan Perancangan Analisis dan Interprensinya. Fakultas Pertanian, Universitas Brawijaya. Malang. 